\title{
Marketing Mix Strategy and Physicians' Satisfaction: A Mediation Effect of Perceived Value in the Pharmaceutical industry in Yemen
}

\author{
${ }^{1}$ Murshid, M,A., ${ }^{2}$ Halim, M, S ${ }^{3}$ Osman, A \\ ${ }^{1,2,3}$ School of Business Innovation and Technopreneurship University Malaysia Perlis (UniMAP)
}

\begin{abstract}
This research attempts to examine the mediation effect of perceived value on marketing mix strategy and physician satisfaction with locally manufactured drug in Yemen. 300 physicians were selected as the sample size. Multiple regressions analysis was run to test the hypotheses. Based on the 170 completed data, the findings provide support for the relationship between marketing mix strategies (product, price, place and promotion) and physician satisfaction. The findings also confirm that perceived value is a critical antecedent to physician satisfaction. In addition, price, place and promotion are important predictors of perceived value, and perceived value has a strong positive relationship with satisfaction. In short, marketing mix strategy drives perceived value which in turn drives Physician satisfaction. The results also indicate that perceived value partially mediates the relationship between marketing mix strategy and physician satisfaction. As a result, the strength of the marketing mix strategy - physician satisfaction relationship becomes weaker when perceived value is considered. Managerial and theoretical implications of the findings are also discussed.
\end{abstract}

Keywords: Marketing mix strategy, Perceived value, Physician satisfaction, mediation effect.

\section{Introduction}

Customer satisfaction (CS) plays an important, if not a critical role in a firm's success .The significant role of customers' satisfaction is a necessary foundation for a company to retain the existing customers and also the key element in any customers' retention strategy in the future (Guo et al., 2009; Oliver, 1999). According to Kotler (2006), "One key to customers' retention is customers' satisfaction; a satisfied customer stays loyal longer". The result of a successful customer satisfaction strategy leads to customer loyalty (Kuo et al., 2009). With satisfaction customers, pharmaceutical companies can maximize their profitability, market share, and investment return (Anderson, Fornell, and Lehmann, 1994). Satisfaction physicians are willing to recommend drugs to others (patients) (Sweidan et al., 2012; Kalaskar et al., 2012). Hence, physician' satisfaction is very important element for pharmaceutical companies in the pharmaceutical industry (Sweidan et al 2012).

Previous research has linked marketing mix strategy (MMS) to perceived value (PV) (Cengiz et al., 2007) and customer satisfaction (Faryabi et al., 2012; Molner, 2007). In the aspect of the pharmaceutical industry, studies regarding MMS, PV and customer satisfaction issues are very limited and scanty. A few studies have suggested that perceived value is a key determinant of satisfaction due to its primary role in to explain CS (Woodruff, 1997; Lee et al., 2007; Wang et al., 2006). Other studies went a step further by investigating the mediating effect of perceived value on marketing mix strategy (e.g. product quality and price) - customer satisfaction (Uddin et al., 2012; Malik, 2012). However, there is no consistent result found in pharmaceutical industry. Moreover, recent study by Li et al. (2011) suggested examining the mediation of perceived value on relationship between MMS and satisfaction. Hence, the main purpose of this research is to answer the question; is there any mediating effect of perceived value on the relationships between MMS and physician satisfaction.

Yemen, pharmaceutical industry has become one of the important industries sector that contributing for country's economic development. According to the final report of the results of the industrial survey (2011) pharmaceutical industry belongs to large industries and contributes about $10.7 \%$ of GDP to the national economy from the perspective of standards industrial survey of year (2011). According to Arab Union of Producers medicine and Medical Appliances, (AUPMA, 2011), Yemen ranked 11th position out of the 14 Arabic countries in terms of drug production in the year of 2011. It produces the equivalent of 94 million dollars and the value of the volume of the local consumption of drug in Yemen 94 million dollars (AUPR, 2011). According to Supreme Board of Drug and Medical Appliances (SBDMA) annual report (2012), the number of local pharmaceutical manufacturers in Yemen is nine companies produce more than 500 brands and cover the equivalent of $9.24 \%$ of domestic consumption of drugs. Recently, local pharmaceutical manufacturers faces some problems such as mistrust among physicians and inadequate marketing, increased competition where that the Yemeni market is become more open to foreign pharmaceutical companies. Local pharmaceutical 
companies have no competency to compete with foreign companies from about 69 countries and more than 400 companies (Al-Hamdi et al., 2012).

\subsection{Marketing mix strategy (MMS)}

\section{Literature Review}

Marketing mix strategy blending of the four-strategy elements namely product, price, place and promotion that use by company (s) to satisfy the needs and wants of target customers at a profit (McCarthy ,1971). It is interrelated, integrated and equally important (McCarthy, 1971). MMS related product, price, promotion and place are considered the needed tools used by the pharmaceutical companies to influence physicians' behavior (Kalaskar et al., 2012; Sultana et al., 2011). Customer satisfaction is the result of successful MMS that creates more competitive value for customers (McCarthy, 1971; Kotler and Armstrong, 2008). MMS model (4Ps) has become the worldwide acceptable marketing model in all industries including pharmaceutical industry (Kalaskar et al., 2012) and has had an extraordinary effect on marketing practices (Kotler, 2005; Gronroos, 1994). In pharmaceutical industry context, empirical studies found that MMS directly influence on behavior physician (Obaidat et al., 2011; Sultana et al., 2011; Kalaskar e al., 2012). In marketing literature context, MMS has a significant impact on satisfaction (Aimin et al., 2012; AlMuala et al., 2012; Irtaimen, 2012) and perceived value (Cengiz\&Yayla, 2007; Faryabi et al., 2012; Yoo et al., 2000). Therefore, MMS always linked to with any marketing variables such perceived value and satisfaction as in this research.

Satisfaction of customer is result of successful MMS; product, price, place and promotion (4Ps). For product means the company can offer high quality product (Churchill et al., 1982; Oliver; 1993). Price means that company can offer competitive price (Dodaz et al.1991 and Yoo et al.2000; Uddin et al., 2012 ) or acceptable price (Obaidat et al., 2011), the place means that the customers to get the product in right time and the right place (Copley, 2004;Aimin and Begum,2012 ), and the promotion refers that company can communicate to the customers about its products(Al Mula et al., 2012) .Thus, MMS namely product, price promotion and place is an important variables that needs an extensive study in pharmaceutical industry, because it will cause actual customer satisfaction(Cengiz and Yayla, 2007; Kotler, 2003; Constantinides, 2006).

\subsection{Perceived value (PV)}

Perceived value is customer perceptions of what you (customer) get for what pay (Tradeoff)(Zithamal,1988; Monoro,1990) .PV is a construct containing two dimensions, one of benefits received (Sprang et al., 1993; Zeithaml, 1988; Monroe, 1990) and another of sacrifices made by the customers (Dodd's et al., 1991; Cronin et al., 2000; Cengiz et al., 2007). The benefits are outcomes of the product or service that lead to the higher level of values perceived by customers. It can be measured by the attribute quality, perceived quality (Yoo et al., 2000). Perceived sacrifices consist of monetary sacrifice (price) and nonmonetary cost (cost, time, and effort) may be thought of by many customers as the maximum sacrifices (Cronin et al., 2000; Cengiz et al., 2007). In addition ,several researchers suggest that perceived value is the ratio between customer's perceived quality earned and price or cost (monetary \& non-monetary) paid (Rust et al., 2004; Gale,1994;Li et al., 2011). Several studies have also founds that perceived Value has a significant impact on customer satisfaction (Faryabi et al., 2012; Spiteri et al., 2004). PV is a mediator between MMS (product) or service quality (Malik, 2012), price (Uddin et al. 2012) and customer satisfaction . Perceived value is resulting MMS and lead to satisfaction (Cengize et al., 2007; Faryabi et al., 2012). Moreover, perceived value can be viewed is an independent variable (Ishaq et al., 2012) or a mediating variable (Yoo et al., 2000; Malik, 2012; Uddin et al., 2012). Perceived value can measured by perceived quality (Yoo et al, 2000), perceived sacrifice (Ishaq et al., 2012), two dimensions of quality and price (Malik, 2012). When PV is a mediator, researchers (Malik, 2012) measure it from perceived quality aspect (Yoo et al., 2000) or quality and price (Malik, 2012). Dodds et al. (1991) examined the effects of mediation of perceived value (quality and sacrifice) on relationship between price store information and brand with willingness to purchase. As result, this research measure perceived value as a total measure of perceived quality and perceived sacrifice (Li et al., 2011; Dodd's et al., 1991; Malik, 2012; Zithamal, 1988). Perceived value refers to the physician evaluation of the perceived quality and perceived sacrifice of a drug product by based on their patients advance sacrifices and ex-post perceived quality when they use drug.

\subsection{Physician Satisfaction}

Satisfaction can be classified into two different approaches (Boulding et al., 1993), transaction specific satisfaction (Churchill et al., 1982) or a cumulative satisfaction / post -use or consumption satisfaction (Fornell, 1992). After 1990s, many researchers suggested that satisfaction as customer cumulative, after use or purchase (Johnson, 2002). Fornell (1992) defined CS as "the customer's overall evaluation of the consumption experience to date". In this context, CS refers to physician satisfaction, which is a component of overall customer satisfaction that could be described as the overall evaluation of the physician of local drugs based on experience 
of the use of a drug over time. Within the pharmaceutical industry, physician satisfaction can be considered as an important component and measure of the quality of drug. MMS and perceived value were examined as the strongest antecedents of satisfaction (Cengiz et al., 2007; Faryabi et al., 2012; Malik, 2012). Perceived value is found to be the most important influence to predict customer satisfaction (Ardabili et al., 2012, Uddin and Akhter, 2012). Perceived quality and perceived sacrifice are sub dimensions of perceived value which have a positive effect on satisfaction, also perceived sacrifice (Carmen et al., 2013; Tsiotsou, 2005). Satisfaction is result of marketing mix and perceived value (Faryabi et al., 2012, p.80). Thus, MMS and perceived value are key determinants of physician satisfaction (Lee et al., 2007; Wang et al., 2006; Moliner et al., 2007).

\section{4 Linking between Marketing Mix Strategy, Perceived Value, and Satisfaction}

Although several studies have investigated the relationship of MMS, perceived value and satisfaction in different industries, no study that examines the mentioned relationship in the pharmaceutical industry was found. Hence, this research attempts to examine the mediating effect of perceived value towards the relationship between MMS of locally manufactured drug and physician satisfaction. AlMuala et al. (2012) indicated that there is a strong link between MMS and satisfaction. It was also believed that customer satisfaction is a result for marketing strategies (Faryabi et al.,2012; Cengiz et al., 2007 ) and perceived value (Cronin, Brady, and Hult, 2000; Spiteri and Dion, 2004: Lee et al., 2007 ; Uddin and Akhter, 2012). According to Cengiz et al. (2007), price, place, promotion have affects the customer satisfaction of accounting offices. Research in veterinary pharmaceutical industry revealed that customer perceived value has a positive influence on overall satisfaction of physicians (Spiteri and Dion, 2004). Kalaskar et al. (2012) who conducted a research among physicians concluded that all marketing mix strategies have effect on physician's behavior. According to Al Ghadeer and Obaidat (2012), found that overall MMS has a positive relationship with customer preference towards the drug.

The effect of MMS on customer satisfaction takes on different forms: direct effect or indirect effect through perceived value (Malik , 2012; Uddin et al., 2012 ). For the direct influence, several studies in different industries have shown that MMS is an antecedent to satisfaction (Bloemer et al., 2002; Aimin et al., 2012; Irtaimen, 2012; ALMuala et al., 2012). In pharmaceutical settings, few evidences have also indicated that the direct effect exists (Obaidat et al.,2012). When customers' (physicians) perception of marketing mix are high, the satisfaction are favorable, which strengthen their relationship with the drug product or company. In the banking industry, the marketing mix strategies are positively and directly related with perceived value and customer satisfaction (Faryabi et al., 2012).

Perceived value is found to positively influence satisfaction (Chen et al., 2008; Raza et al., 2012). Perceived value for tourist significantly and positively influences tourist satisfaction (Chen and Chen 2010). Malik (2012) indicated that overall perceived value (quality and price) is a good mediating variable between MMS (product quality) and satisfaction. Other evidence of the mediating effect of perceived value has been found in telecom industry between MMS (price) and satisfaction (Uddin and Akhter, 2012). In other study by Li and Green (2011), the researchers found that perceived value has a mediating effect on the relationships between marketing mix strategy and customer loyalty. They also recommended studying the mediation effect of perceived value between MMS and satisfaction in different industries.

\section{Research Methodology}

This research was of a survey design which employs the use of questionnaire as a main tool to collect data. Questionnaire was included close-ended questions to measure constructs used in study and specific questions to measure the demographic characteristics of respondents.

\subsection{Measures, frame work and hypotheses}

Marketing mix strategy was measured by product; price, promotion, and place with 19 items. The items were adapted from (Bradley, 2001; Yoo et al 2000; Cengiz et al., 2007; Kalaskar et al., 2012). Perceived value was a total measure of perceived quality and perceived sacrifice proposed by Li et al. (2011) with 9 items. Perceived quality was measured using 4 items adopted from Yoo et al. (2000) and five items adopted from Cronin et al. (2000) to measure perceived sacrifice. Customer (physician) satisfaction was measured using five items (overall satisfaction) adapted from Bloemer et al. (2002). A five point Likert-type scale, ranking from (1) for 'Strongly Disagree' to (5) for 'Strongly Agree' was used to measure the MMS scales, perceived value and the physician satisfaction . 


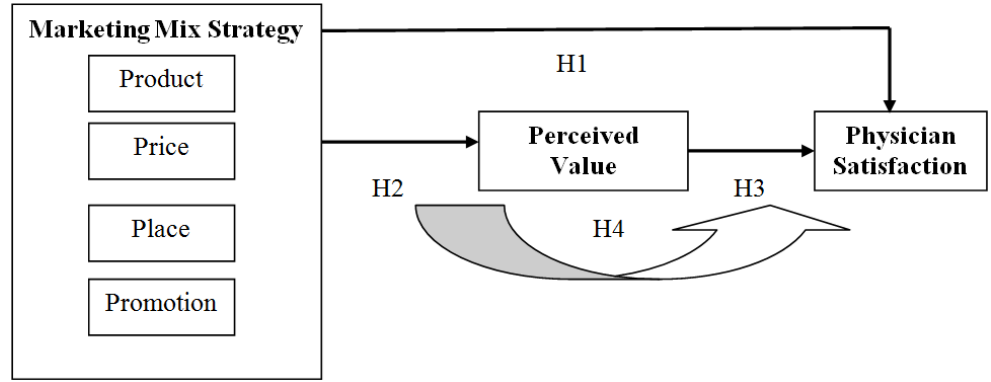

Figure 1. Research frame work

\subsection{Hypotheses Development}

According to Figure 1 shows the proposed hypotheses were developed as follow: H1: A significant relationship exists between MMS and physician satisfaction.

H2: A significant relationship exists between MMS and physician perceived value.

H3: A significant relationship exists between perceived value and physician satisfaction.

H4: Perceived value mediates the relationship between MMS and physician satisfaction.

H4 (a): Perceived value mediates the relationship between product and physician satisfaction.

H4 (b): Perceived value mediates the relationship between price and physician satisfaction.

$\mathrm{H} 4$ (c): Perceived value mediates the relationship between place and physician satisfaction

H4 (d): Perceived value mediates the relationship between promotion and physician satisfaction.

\subsection{Pilot Test}

To achieve efficiency in the data collection process, the researcher has conducted a pre-test in September 2013. The main purpose of pilot study is to test the goodness of measure. The pilot study for the current research was conducted to check the reliability and validity of items for the three main constructs and to test the effectiveness of the questionnaire in terms of the simplicity and the understanding by the respondents. A self-administered questionnaire method to 30 physicians was used to distribute the questionnaire which is $10 \%$ of the sample for the main study (Churchill et al., 1995). The descriptive analysis (mean and standard deviation) and measure of Cronbach alpha Coefficient of each constructs were calculated to assess internal consistency reliability and validity of instruments. The findings of the cronbach alpha indicate that most of the items used to measure the constructs have a value more than 70 . However, one item of price variable and two items for measure perceived quality were removed, because the corrected items less than 30 (Nunnally, 1987).

\subsection{Population, sample and Sample size}

The research population consists of the physicians of private and public sectors who working in different clinics and hospitals in Yemen. A sample size of 300 was chosen for this research. Taking into account the size of samples needed to conduct the factor analysis and multiple regression analysis. Out of 300 questionnaires 192 was returned, but 170 was usable to final analysis. Since the focus of this research is in specific locally manufactured drugs in Yemen, a non-probability purposive judgmental sampling is considered to be the most appropriate method (AlMuala et al., 2012) that this method practically included the selection of the physicians who can provide reliable and fastest information from others therefore, they were believed to be able to fulfill the research requirement.

\subsection{Data collecting Method and Tool}

The data was gathered by using a mean self-administered questionnaire. The questionnaire has 8 sections. In Section 1, 6 items to measure the respondent's demographic variables. In section 2, 3, 4 and 5, 19 items to measure marketing mix strategies were used. In section 6and7, 9 items to measure perceived value were used. In section 8 , five items to measure the physician satisfaction were used. The items were formatted using 5points Likert scale such as ' 1 ' for 'Strongly Disagree' and '5' for 'Strongly Agree'.

\section{6 Data analysis and findings}

To test the reliability of the instruments, Cronbach's alpha was used. The reliability and mean of the marketing mix strategy scale, perceived value and physician satisfaction used were calculated. According to Nunnally (1987) if the Cronbach's alpha coefficient is 0.60 or less, the results related to internal consistency are not satisfactory. However, Sekaran, (1996) indicate that lower values than 0.60 is considered acceptable. In this research, the reliability coefficient of 0.70 was used. When Cronbach's alpha is higher, the reliability also increases due to the value of correlation coefficient between variables. The result of Cronbach's alpha in mean study indicated that all constructs have a value more than 70 . This mean it was acceptable for further analysis 
(see Table 1). Moreover, multiple regression analysis was run to test proposed hypotheses in this study. Following the suggestion from Baron and Kenny (1986), the relationship between independent and dependent variables was tested through 4 steps.

\subsection{Respondent Profiles}

\section{Results}

The demographic features of the respondents were analyzed. Out of 170 respondents, $141(82.9 \%)$ are female and $29(17.1 \%)$ are male. About $47.6 \%$ of the respondents are Master qualification, and the remaining are Doctorate and others. Majority (41\%) of respondents ages between 35 and 45 years old. Specialty Surgery is the largest of 54 respondents. The respondent (physicians) who worked in the medicine for between 5 and 10 years was represented by 60 or $35.3 \%$. Majority (52.9\%) of the respondents preferred to choose the drug based on quality.

4.2 Reliability Analysis and Descriptive Statistics

Table 1. Descriptive and reliability analysis results $(n=170)$

\begin{tabular}{lllcc}
\hline Variable & Number of Items & Mean & SD & Cronbach's alpha \\
\hline Product & 6 & 2.99 & 0.70 & 0.85 \\
Price & 3 & 3.29 & 0.77 & 0.79 \\
Place & 5 & 3.18 & 0.69 & 0.81 \\
Promotion & 5 & 2.96 & 0.74 & 0.80 \\
Overall MMS & 19 & & & 0.86 \\
Perceived Quality & 5 & 2.825 & 0.81 & 0.90 \\
Perceived Sacrifices & 4 & 3.020 & 0.71 & 0.79 \\
Overall Perceived value & 9 & & & 0.87 \\
Physician satisfaction & 5 & 3.060 & & 0.93 \\
\hline
\end{tabular}

As shown in table 1, the alpha values were calculated to assess the internal consistency reliabilities of the instruments. The alpha value for marketing mix strategies are as follows: product $(\alpha=0.85)$, price $(\alpha=$ $0.79)$, place $(\alpha=0.81)$, and promotion $(\alpha=0.80)$. The overall MMS score is a high $(\alpha=0.86)$. For physician satisfaction scales, the alpha results indicate is very high value $(\alpha=0.93)$. The alpha value for overall perceived value is a high $(\alpha=0.87)$. In summary, the coefficient alpha value for MMS, perceived value and physician satisfaction are above 0.70 . Thus, the item scales are highly reliable (Nunnally, 1987). The mean scores for all strategies are as follows: product (2.99), price (3.29), place (3.18), and promotion (2.96). Physician satisfaction shows the mean score of 3.060. Most of constructs have a standard deviation above 0.70 , which is considered as good.

\subsection{Test of Hypotheses}

The multiple regression analysis and hierarchical regression were conducted as suggested by Baron and Kenny (1986), by running four steps of analysis separately (refer to Table 2 to Table 5).

\subsubsection{Hypotheses H1-H3}

The results of multiple regression analyses support to $\mathrm{H} 1, \mathrm{H} 2$ and $\mathrm{H} 3$ (see Table 2, 3 and 4).

H1: A significant relationship exists between MMS and physician satisfaction (Table 2)

H2: A significant relationship exists between MMS and physician perceived value (Table 3).

H3: A significant relationship exists between perceived value and physician satisfaction (Table 4).

Table 2. Step 1-regression analysis of marketing mix strategies with physician satisfaction

\begin{tabular}{lcccccccc}
\hline \multicolumn{1}{c}{ construct } & $\mathrm{B}$ & $\beta$ & $\mathrm{t}$-value & $\mathrm{p}$-value & $\mathrm{R}$ & $\mathrm{R}^{2}$ & F-value & $\mathrm{F}$-sig \\
\hline Constant & -.93 & & -3.41 & 0.00 & .57 & .56 & 55.6 & 0.00 \\
Product & .33 & $\mathbf{. 2 6}$ & 4.56 & 0.00 & & & & \\
Price & .34 & $\mathbf{. 3 0}$ & 4.78 & 0.00 & & & & \\
Place & .36 & $\mathbf{. 2 9}$ & 4.87 & 0.00 & & & & \\
Promotion & .22 & $\mathbf{. 1 9}$ & 3.41 & 0.00 & & & & \\
Constant & -.88 & & -3.20 & 0.00 & .55 & .55 & 208.5 & 0.00 \\
Overall MMS & 1.27 & $\mathbf{. 7 4}$ & 14.44 & 0.00 & & & & \\
\hline
\end{tabular}

Note: Significant is at 0.05 level 
Table 3. Step 2-regression analysis of marketing mix strategies with perceived value

\begin{tabular}{lcccccccc}
\hline construct & $\mathrm{B}$ & $\beta$ & $\mathrm{t}$-value & $\mathrm{p}$-value & $\mathrm{R}$ & $\mathrm{R}^{2}$ & F-value & F-sig \\
\hline Constant & .27 & & .95 & 0.00 & .45 & .45 & 35.25 & 0.00 \\
Product & .07 & $\mathbf{. 0 7}$ & 1.11 & 0.26 & & & & \\
Price & .27 & $\mathbf{. 3 1}$ & 4.45 & 0.00 & & & \\
Place & .22 & $\mathbf{. 2 2}$ & 3.38 & 0.00 & & & \\
Promotion & .29 & $\mathbf{. 3 1}$ & 5.04 & 0.00 & & & \\
Constant & .27 & & 11.11 & 0.26 & .42 & .42 & 122.4 & 2.65 \\
Overall MMS & .86 & $\mathbf{. 6 5}$ & 11.06 & 0.00 & & & & \\
\hline
\end{tabular}

Note: Significant is at 0.05 level

Table 4. Step 3-regression analysis of perceived value with physician satisfaction

\begin{tabular}{lcccccccc}
\hline construct & $\mathrm{B}$ & $\beta$ & $\mathrm{t}$-value & $\mathrm{p}$-value & $\mathrm{R}$ & $\mathrm{R}^{2}$ & F-value & F-sig \\
\hline Constant & .61 & & 2.66 & 0.00 & .41 & .41 & 166.9 & 0.00 \\
Perceived value & .82 & $\mathbf{. 6 4}$ & 10.81 & 0.00 & & & & \\
\hline
\end{tabular}

Note: Significant is at 0.05 level

The results are consistent with other studies that show marketing mix strategy is an antecedent to customer satisfaction (Cengiz et al, 2007; Huddleston et al., 2009; Al Muala et al., 2012)

Moreover, marketing mix strategy has a significant positive influence on perceived value (Faryabi et al., 2012 Cengiz et al, 2007). Perceived value meanwhile significantly affects physician satisfaction (Uddin et al., 2012 , Raza et al., 2012; Spiteri and Dion (2004).

\subsubsection{Hypotheses 4 (testing the mediating effect of perceived value)}

This research found that perceived value partially mediates the MMS-physician satisfaction relationship. From Table 2 , product $(\beta=0.26, p=0.00)$, price $(\beta=0.30, p=0.00)$, place $(\beta=0.29, p=0.00)$ and promotion $(\beta=0.19, \mathrm{p}=0.00)$ Strategies have a significant positive effect on physician satisfaction. From Table 3, price $(\beta=0.31, \mathrm{p}=(0.00)$, place $(\beta=0.22, \mathrm{p}=0.00)$ and promotion $(\beta=0.31, \mathrm{p}=0.00)$ strategies have a significant positive effect on perceived value. However, product $(\beta=0.07, p=0.26)$ no significant effect on perceived value .Hence, this variable was dropped in test mediation in step 4 as suggested by Baron and Keny (1986). If any variable showed insignificant result, this variable will be removed for the mediation test in step four. Therefore, perceived value mediates the relationship between product and satisfaction no test. Table 5 provides Step 4- the summary of beta value for the independent variables on physician satisfaction before (step1) and after including the perceived value variable (step 2) in the hierarchical regression.

Table 5. Step 4- summery of mediating effect of perceived value on the relationship between marketing mix strategies and Physician satisfaction

\begin{tabular}{lcc}
\hline \multicolumn{3}{c}{ Criterion Variable } \\
Physician Satisfaction
\end{tabular}

Note: Significant is at 0.05 level

As shown in table 5 (step 4). MMS has a significant effect on physician satisfaction $(\beta=0.74, p=0.00)$ in step 1. When perceived value is considered as a mediating variable in step 2 , it is suggested that perceived value partially mediates the relationship between MMS and physician satisfaction $(\beta=0.56, p=0.00)$. The $R^{2}$ value increased from 0.55 (step1) to 0.59 (step 2) and the $\beta$ value reduced from 0.74 (step1) to 0.56 (step2). Thus, H4 is partially supported. From table 5 , price $(\beta=0.41, p=0.00)$, place $(\beta=0.28, p=0.00)$, promotion $(\beta$ $=0.25, \mathrm{p}=0.00$ ) all have a significant effect on physician satisfaction (in step 1). When the perceived value is considered as a mediating variable in step 2 , the $\mathrm{R}^{2}$ value increased from 0.52 (step1) to 0.56 (step 2). And also, the $\beta$ value is reduced. For price, from 0.41 (step1) to 0.31 (step2), place from 0.28 (step1) to 0.22 (step2), and promotion from 0.25 (step1) to 0.15 (step2). Thus, the H4 (b), H4(c) and H4 (d) are supported. According to Baron and Kenny (1986) partial mediation takes place when the significant relationship between independent variable and dependent variable is reduced. According to Hair et al (2010), t he higher the value of $R^{2}$, the greater the explanatory power of the predictor variables will be. This result is consistent with Uddin et al. 
(2012) who indicated that perceived value is a good mediating variable between MMS (price) and positive satisfaction. The finding offers support to other researches such as (Li et al, 2011; Faryabi et al., 2012).

\section{Discussion}

The findings research indicates that marketing mix strategies affect both perceived value and satisfaction. Promotion and price are the most powerful predictors of perceived value for physicians. On the other hand, price and place strategies are the most powerful predictors of physician satisfaction. In addition, perceived value mediates the relationship between price, place and promotion on physician satisfaction. These results explain that if physicians are satisfied with the product of the locally manufactured drug, they will have high satisfaction to use the drug.

The product attributes such as quality of drug, efficiency, effectiveness, and reputation are classified under the product. The effect of product on satisfaction $(B=0.26, t=4.56)$ is stronger as compared to the effect of perceived value on perceived value $(B=0.07, t=1.11)$. As such, the local pharmaceutical companies should put in serious efforts to improve quality drugs and it technically sound, and as they get to use the latest technology in manufactures of drug might enhance the physician satisfaction. From time to time, the pharmaceutical companies should invest on research and development of products to ensure that products are sufficient in terms of quality and effectiveness. The price of locally manufactured drug aspects such as good value for many and reasonable prices for competitors and benefits are classified under price has affected both perceived value and satisfaction. The effect of price on perceived value $(B=0.30, t=4.45)$ is stronger as compared to the effect of price on satisfaction $(B=0.31, t=4.78)$. This mean that perceived value for physician is influenced by price. At the same time the he price of drug have positive direct influence on physician satisfaction. Thus, the positive effect of low and responsible price and perceived value makes physicians satisfied. Managers should have planning to ensure product quality, competitive price, increased perceived value of physicians to achieve competitive advantages over their rivals.

Place refers to the availability of the drug product to the targeted customers. In this study, the effect of place on satisfaction $(\mathrm{B}=0.29, \mathrm{t}=4.87)$ is stronger as compared to the effect of place on perceived value $(\mathrm{B}=$ $0.22, \mathrm{t}=3.38$ ). Mangers should pay attention to how it can deliver the drug product at the right time and at the right place, and which channel will be used to deliver the product to customers. The promotion refers set of activities carried out by the pharmaceutical companies in order to communicate with its existing and potential physicians. Promotion is considered as the first important strategy in determining perceived value for physicians $(\mathrm{B}=0.31, \mathrm{t}=5.04)$. This means that promotional activities may have a positive relationship to physician perceived value. Logically, promotional activities will create drug product, product knowledge, and product attribute and benefits and persuade physicians to prescribe the product and use it. If satisfied, it may lead to perceived value, and physician satisfaction.

\section{Conclusions and implications}

The results of this research provide some implications for local pharmaceutical companies or similar industry in Yemen. The significant effects of two exogenous variables imply that research in physician satisfaction should take into account not only factors such as MMS and perceived value but also other potentially important factors, such as price as well as place. In this research, we extend the existing physician satisfaction model by incorporating two main antecedents in the proposed model, presenting a more comprehensive picture of perceived value and physician satisfaction. Therefore, theory building in this area could benefit from examining the issues from multiple perspectives to provide additional insights. From a managerial perspective, marketing mix strategy, and perceived value is an important influencing factors on physician satisfaction. Companies should understand the importance of quality and variable of the drug to customers. Perceived value for physician is influenced by marketing mix strategy (price, place and promotion). At the same time product, price, place and promotion have positive direct influence on physician satisfaction. Thus, the positive effect of quality, low price, available and promotion of drug and perceived value makes physician satisfied. Managers should have planning to ensure product quality.

As a summary, knowledge about the physician's perception towards marketing mix strategies for pharmaceutical companies is one of the most important steps towards improving the pharmaceutical industry in Yemen. Identification of strategies that require immediate improvement in locally manufactured drug valuable guidance to the managers and policy makers who can devise suitable marketing strategies to make these local drugs more quality and effectiveness to the needs of the customers and physicians. This can lead to restoration of faith in the locally manufactured drug and subsequently contribute to an improvement in a physician's satisfaction. Finally, this research could guide researchers to better understand how MMS, perceived value and satisfaction interact in pharmaceutical industry. Pharmaceutical company's marketing managers can use the current findings to develop marketing strategies that will enhance physician perceived value and to improve physician satisfaction. 


\section{Limitations and Future research}

From the results on the explanatory power of marketing mix strategy on overall physician satisfaction, it can be concluded that although MMS is an important factor in influencing physician satisfaction $\left(\mathrm{R}^{2}=0.55\right)$, there are other factors or variables that may contribute in enhancing overall customer satisfaction. Future research should try to include more factors than marketing strategies such as product quality, distribution intensive and other promotion strategies. The current research is limited to measuring the marketing mix strategy of locally manufactured drug from physicians' perspective . Future studies should embark on measuring and comparing the marketing mix strategy of drugs in both local and foreign in Yemen. And also in terms the respondents comparing between physicians and pharmacists may contribute to the body of knowledge. Moreover, the current research is limited to measuring the perceived value as a total measure of perceived quality and perceived sacrifice dimensions. Future study should study these dimensions separately on satisfaction in pharmaceutical industry or similar industries. Finally, the present research has provided strong support for the ability of marketing mix strategy to predict physician satisfaction. Marketing mix strategies such as product, price place, and promotion are predictors to physician satisfaction. Price, place and promotion strongly predict physician perceived value. However product has no influence on perceived value. The strengths of the relationship between marketing mix strategy and satisfaction is stronger compared to the perceived value -satisfaction relationship. Nevertheless, the research in this area (pharmaceutical) is not conclusive. Further investigation is required (in different industries and countries) using a wider marketing strategies and larger samples, in order to draw more definite conclusions.

\section{References}

[1]. Aimin,W. \& Begum, S.(2012). Investigating the impact of marketing mix elements on tourists'satisfaction: An empirical study on East Lake. European Journal of Business and Management, 4(7) , 373-283.

[2]. Al-Hamdi, A. , Hassali, M. \& Izham, M. (2012). Impact of pharmaceutical promotion on healthcare professional's practices and behavior views from general practitioners, medicine dispensers and medical representatives in Yemen. Journal of Medical Marketing: Device, Diagnostic and Pharmaceutical Marketing. 0(0), 1-7.

[3]. Alireza, S. Mosavi \& Ghaedi, M. (2011). A survey on the relationships between perceived value and customer advocacy behavior. International Conference on Innovation, Management and Service IPEDR, 14, IACSIT Press, Singapor.

[4]. Al Muala, A. \& Al Qurneh, M. (2012). Assessing the relationship between marketing mix and loyalty through tourists satisfaction in Jordan curative tourism' American Academic \& Scholarly Research Journal, 4, (2).

[5]. Anderson, Eugene W., Claes Fornell, and Donald R. Lehmann. (1994). "Customer Satisfaction, Market Share, and Profitability: Findings from Sweden." Journal of Marketing 58 (July): 53-66.

[6]. Ardabili, F.S., Daryani, S.M., Molaie, M., Rasooli, E. \& Kheirava, M. (2012). 'Importance of mutual relations on customer satisfaction in industries with no/low direct contact with customers' African Journal of Business Management, 6(29), 8637-8643.

[7]. AUPMA Annual report (2011). Jordan: Arab Union of Producers medicine and Medical Appliances, 2011.

[8]. Baron, R. M., \& Kenny, D. A. (1986). The moderator-mediator variable distinction in social psychological research: Conceptual, strategic and statistical considerations. Journal of Personality and Social Psychology, 51(6),1173-1182

[9]. Bloemer, J. \& Odekerken-Schröder, G. (2002). Store satisfaction and store loyalty explained by customer- and store-related factors. Journal of Consumer Satisfaction, Dissatisfaction and Complaining Behavior, 15, 68-80.

[10]. Boulding, W., Kalrs, A., Staelin, R. \& Zeithaml, V.A. (1993), - A Dynamic Process Model of Service Quality: from Expectations to Behavioral Intentions. Journal of Marketing Research. Vol. 30, No. 1, pp. 7-27.

[11]. Bradley, F. (2001), "Country company interaction effects and supplier preferences among industrial buyers", Industrial Marketing Management, 30, pp. 511-524.

[12]. Carmen,p.,Pop,N.(2013). The relationship between perceived sacrifice and B to B customer satisfaction in the insurance industry. JEL codes: M31, M39.

[13]. Cengiz, E. \& Yayla, H.E. (2007). The effect of marketing mix on positive word of mouth communication: Evidence from accounting offices in Turkey. Innovative Marketing, 3(4), 73-86.

[14]. Chen, C.F., Tsai M.H.(2008). Perceived value, satisfaction, and loyalty of TV travel product shopping: Involvement as a moderator. Tourism Management 29 (2008) 1166-1171.

[15]. Chen, C-F., and Chen, F-S. (2010), "Experience quality, perceived value, satisfaction and behavioral intentions for heritage tourists", Tourism Management, 31, 29-35.

[16]. Churchill, Gilbert A. Jr. and Carol Surprenant (1982), "An Investigation into the Determinants of Customer Satisfaction," Journal of Marketing Research, 19 (November), 491 -504.

[17]. Churchill, A. G. \& Peter, J.P. (1995). Marketing: Creating Value for Customers. Burr Ridge, IL:Irwin.

[18]. Constantinides, E. (2006). The Marketing Mix Revisited: Towards the 21st Century Marketing," Journal of Marketing Management: 407-438.

[19]. Copley, P. (2004). Marketing communications management: concepts and theories, cases and practices Oxford: ButterworthHeinemann.

[20]. Cronin, J.J., Brady, M.K., \& Hult, G.T.M. (2000). Assessing the effects of quality, value, and customer satisfaction on consumer behavioral intentions in service environments. Journal of Retailing, 76(2), 193-218.

[21]. Dodds, W.B., Monroe, K.B., \& Grewal, D. (1991). Effects of price, brand, and store information on buyers' product evaluations. Journal of Marketing Research, 28(3), 307-319.

[22]. Faryabi, M., Kaviani F., \& Yasrebdoost, H. (2012). The relationship between customer perceived value and customers Satisfaction The Banking Industry in Iran' Australian Journal of Basic and Applied Sciences, 6(12),76-85,

[23]. Fornell C (1992). A national satisfaction barometer: the Swedish experience. J. Mark., 56(1):6-21.

[24]. Gale, B. (1999).Customer value measurement: Gaining Strategic Advantage. Consortium Benchmarking Study, Best Practice Report by American Productivity \& Quality Center, Retrieved December 14, 2009.

[25]. Gronroos, C. (1994). From Marketing Mix to Relationship Marketing: Towards A Paradigm Shift in Marketing. Management Decision, 32(2), 4-20. 
[26]. Guo, L., Xiao, J. J., \& Tang, C. (2009). Understanding the psychological process underlying customer satisfaction and retention in a relational service. Journal of Business Research, 62, 1152.1159.

[27]. Huddleston, P., Whipple, J., Mattick, R.N., \& Lee, S.J. (2009). Customer satisfaction in food retailing: Comparing specialty and conventional grocery stores. International Journal of Retail \& Distribution Management, 57(1), 63-80.

[28]. Hair J.F. JR, Black, WC, Babin, B.J. \& Anderson, R.E. (2010). Multivariate Data

[29]. Analysis (7th ed). Upper Saddle River, NJ: Prentice Hall.

[30]. Industrial survey, Annual report. (2011). Sana'a: the results of the industrial survey, Ministry of Industry and Trade, 2011.

[31]. Irtaimen , M.F. (2012). The influences of applying elements of e-marketing mix on customer satisfaction a case study on Jordan Telecom Companies" International Research . Journal of Finance and Economics, Issue 95 (2012).

[32]. Ishaq, M .(2012). Perceived value, service quality, corporate image and customer loyalty: Empirical assessment from Pakistan. Serbian Journal of Management, 7 (1), $25-36$.

[33]. Johnson, Michael D.,Andreas Herrmann B, Anders Gustafsson (2002). Comparing customer satisfaction across industries and countries. Journal of Economic Psychology. Vol. 23, pp. 749-769.

[34]. Kalaskar, P. B. , and Sager P. N (2012). Factors influencing prescription behavior of physicians

[35]. A study with reference to Marathwada Regio: Indian Streams Research Journal, May; 2012.

[36]. Kotler, P. (2003).Marketing Management (11th ed.), New Delhi, India: Prentice- Hall International Edition.

[37]. Kotler, P. (2005). According to Kotler: The World's Foremost Authority on Marketing Answer the World's Foremost Authority on Marketing Answers Your Questions. New York: AMACOM. Lacey

[38]. Kotler, Philip \& Armstrong, Gary (2006). Principles of marketing (11th ed.). New York: Pearson

[39]. International.

[40]. Kotler, P., Armstrong, G., Wong, V., \& Saunders, J. (2008). Principles of marketing (5th ed.): Financial Times/Prentice Hall.

[41]. Kuo, Y-F., Wu, C-M., and Deng, W-J. (2009), "The relationships among service quality, perceived value, customer satisfaction, and post-purchase intention in mobile value-added services", Computers in Human Behavior, 25, 887-896

[42]. Lee, C. K., Y. S. Yoon, and S. K. Lee.(2007). Investigating the Relationships Among Perceived Value, Satisfaction and Recommendations: The Case of the Korean DMZ, Tourism Management,Vol.28, 2007, pp. 204-214.

[43]. Li, M.L. \& Green R.D. (2011). A mediating influence on customer loyalty: The role of perceived

[44]. value. Journal of Management \& Marketing Research . 7(Mar), 1-12.

[45]. Malik, S.U. (2012). Customer Satisfaction, Perceived Service Quality and Mediating Role of PerceivedValue.International Journal of Marketing Studies, 4,(1), 68-75.

[46]. McCarthy, E. J. (1971). Basic Marketing: A Managerial Approach (4th ed.). Homewood, 111. R.D. Irwin

[47]. Moliner, M.A., Sanchez, J., Rodriguez, R.M., \& Callarisa, L. (2007). Relationship quality with a travel agency: The influence of the post-purchase perceived value of a tourism package. Tourism and Hospitality Research, 7(3/4), 194-211.

[48]. Monroe,K.B.(1990).Pricing, Making Profitable Decisions. 2nd ed., McGraw-Hill, New York.

[49]. Nunnally, J. 0. (1 978). Psychometric theory. New York: McGraw-Hill.

[50]. Obaidat, M. \& Al Ghadeer, H. (2011). The Effect of the Medicine Marketing Mix on Jordanian Pharmacists Preference to Local Medicines in Comparison to Foreign Counter Parts. Studies, Management Science, Vol. 38, Issue 201.

[51]. Oliver, Richard L., (1993), "Cognitive, Affective, and Attribute Bases of the Satisfaction

[52]. Response." Journal of Consumer Research, Vol. 20, No 3, pp. 418-430.

[53]. Oliver, R.L. (1999). Whence consumer loyalty? Journal of Marketing, 63(Special issue), 33-44.

[54]. Raza, M., Siddiquei, A., Awan, H. and Bukhari, K.,(2012).Relationship between Service Quality ,Perceived Value ,Satisfaction and Revisit Intention in Hotel Industry. Interdisciplinary Journal of Contemporary Research in Business, 4 (8),788-805.

[55]. Rust, R. \& Oliver, R. (1994), Service Quality - New Directions in Theory and Practice, Sage Publications

[56]. SBDMA. Annual report, 2012. Sana'a: Supreme Board of Drug and Medical Appliances, 2012.

[57]. Sekaran, U. (2006). Research method for business: A skill building approach. John Wiley \& Sons, Inc.

[58]. Spiteria J M , Paul A. Dion.2004.Customer value, overall satisfaction, end-user loyalty, and market performance in detail intensive industries. Industrial Marketing Management,33, 675-687.

[59]. Spreng, R.A, Dixon, A.L and Richard.W.O .(1993). The Impact of Perceived Value on Consumer Satisfaction. Journal of Consumer Satisfaction, Dissatisfaction and Complaining Behavior, 6,50-55.

[60]. Sultana, S.\& Khosru, K.S. (2011). Practice of using gifts as promotional materials for marketing of pharmaceutical products in Bangladesh: A survey conducted on general physicians and representatives from pharmaceutical companies. S. J. Pharm. Sci. 4(2), $13-18$.

[61]. Sweidan,G., Al-Dmour, H., Zu'bi M.F, \& Al-Dmour, R. (2012). The effect of relationship marketing on customer Loyalty in the Jordanian pharmaceutical industry. European Journal of Economics, Finance and Administrative Sciences, 53,153-172.

[62]. Tsiotsou, R . (2005). Perceived quality levels and their relation to involvement, satisfaction and purchase intentions. Marketing Bulletin, 16,1-10.

[63]. Uddin, M. B. \& Akhter, B. (2012). Customer satisfaction in mobile phone services in Bangladesh: A survey research. Management \& Marketing, X (1), 20-36.

[64]. Wong, A. \& Sohal, A.S. (2006). Understanding the quality of relationships in consumer services:

[65]. A study in a retail environment. The international Journal of Quality \& Reliability Management, 23(2/3), 244-264.

[66]. Woodruff, R.B. (1997). Customer value: The next source for competitive advantage .Academy of Marketing Science, 25(2), 139153.

[67]. Yoo, B., Donthu , N. \& Lee, S. (2000). An examination of selected marketing mix elements and brand equity. Journal of the Academy of Marketing Science, 28(2), 195-211.

[68]. Zeithaml, V. (1988). Consumer perceptions of price, quality, and value: A means- end model and synthesis of evidence. Journal of Marketing, 52(July), 2-22. 